\title{
Implementation of Government Policies Regarding the Full Day School Program in the New Normal
}

\section{Santri Prabowo Utomo ${ }^{*}$, Gunarhadi ${ }^{2}$, Sukarno ${ }^{3}$}

${ }^{1}$ Postgraduate Program, Sebelas Maret Universiry Surakarta, Indonesia

2,3 Teacher Training and Education Faculty, Sebelas Maret University Surakarta, Indonesia

A R T I C L E I N F O

Article history:

Received 01 December 2020

Received in revised

Form 06 January 2021

Accepted 28 January 2021

Available online 01

February 2021

Keywords:

Fullday School

Curriculum Policy

\section{A B S T R A C T}

Changes in government policies in the education sector are to prevent the spread of Covid-19. This study aims to explore the results of changes in the learning process of a full-day school. The method used is descriptive qualitative with a case study. Data collected by observation, interview, questionnaire filling, and documentation. Data analysis using interactive qualitative by Miles and Huberman. The results in this study describe the school preparation in implementing changes in government policy about the learning process in a fullday school program during the New Normal. The learning can be well implemented with some development of the school itself following the New Normal Era health protocol in achieving educational goals. The learning in school can be carried out if there are careful preparation and discipline in applying it so the learning can be safely for school residents. The implementation of several changes to health regulations and protocols encourages the emergence of social distancing behavior and minimizes the possibility of a crowd in the school community.

\section{Introduction}

The Covid-19 pandemic outbreak that hit the world brought sudden and urgent changes in various fields. In humans, Covid-19 infects the respiratory tract which generally has symptoms such as colds, dry cough, fever for 14 days, difficulty in breathing, symptoms of kidney failure, pneumonia, and the worst effect is death (Ahmed et al., 2020). This unexpected situation led the Indonesian government to adopt several policies regarding health protocols such as physical distancing, mask use, Pengendalian Sosial Berskala Besar (PSBB), and Perilaku Hidup Bersih Sehat (PHBS) to prevent Covid-19 transmission (Dewi, 2020). One of the affected sectors is in the education sector. Therefore, the government makes policy in the form of learning online from home to prevent the spread of the virus and formulate a policy plan for the implementation of the learning process at school so that students do not get bored at home constantly.

Education is a conscious effort made by a person and is used to shape the quality of self by exploring the potential in him. Not a common thing anymore, quality education can increase the utilization of the development of science and technology precisely and optimally. It is necessary to use appropriate science and technology, accompanied by human resources as competent users, to obtain quality education for the people of Indonesia (Herliandry, Nurhasanah, Suban, \& Kuswanto, 2020). Efforts in overcoming problems and improving the quality of education in Indonesia continue to be encouraged and always pursued by the Indonesian government. Evidence that the government continues to make efforts to improve the quality of education in Indonesia seriously is one of them making policies in the form of development and system changes in regulating the learning process implemented in the New Normal era facing Covid-19 (Khasanah et al., 2020).

Development and changes in the learning process system that is implemented are of course adjusted to the management and circumstances regarding the distribution of Covid-19 in their respective regions in regulating their education. This system change is also about the curriculum used to guarantee the quality of education of a school following the objectives of Indonesia's national education. One of the curriculum systems that is affected is the change in schools that have a full-day school. The concept of this Full day school according to Izzah is that schools are held from morning to evening based on the development of the Ministry of National Education curriculum and enriched with the Ministry of Religion curriculum (Izzah, 2018). This is supported by the opinion of Librianty that Full day School is a school that 
develops and explores the potential and interest of students that are used effectively and optimally through active participation in the learning process that lasts for a full day at school (Librianty, 2018).

In the full-day school program, it does not mean curbing student activities for a full day at school continuously learning and not playing, but there are a method and learning media that includes environmental activities in the classroom and outside the classroom to make students not become bored. This school program is a policy that utilizes student time that is arranged in such a way that more student activity is spent in the school environment to develop their potential rather than at home then after late evening students can return home. The policy is adjusted to the needs of the community around the school. Setiyarini believes that a full-day school is a school that has learning activities such as schoolwork that are usually done at home can be done at school with the guidance of the teacher. through an active, creative, and transformative learning process (Setiyarini \& Joyoatmojo, 2014).

Schools can freely arrange lesson schedules tailored to the weight of each subject and ways to deepen the material which will be developed according to the creativity of each class teacher. Learning process activities usually start from 07.00-15.30 WIB with two opportunities for rest, prayer, and eating food (Iftayani \& Nurhidayati, 2016). This is supported by the opinion of Kristi that the full-day school program integrates the school system in general and students' religious learning in-depth and intensively by giving them extra time after hours of dhuhr prayer to Asr prayer such as activities to develop Aqidah, Akhlak, Hadith, Tafsir, and Arabic accompanied by lunch and nap so that students do not get tired (Kristi Pramudika Sari et al., 2018). Of course, seeing the reality in the field of educational conditions when the Covid-19 outbreak like this made the full-day school program limited and could not be carried out optimally because to support government programs in breaking the chain of distribution.

Government policy during the transition of all activities, especially in the field of education during the Covid-19 pandemic has finally been announced. Minister of Education and Culture, Nadiem Makarim in a press release from the Ministry of Education and Culture Monday, June 15, 2020, announced the results of the Ministry of Education and Culture's decision together with the Task Force for Handling Acceleration of Covid-19, Kemenko PMK, Ministry of Religion, Ministry of Health, Ministry of Home Affairs, BNPB, and Commission X DPR RI in the new academic year 2020/2021 in the epidemic Covid-19 the New Normal era this can already be done face-to-face, especially at the elementary school level if in the area entering the green zone while still following strict health protocols such as students are still required to wear masks, using soap and running water to wash his hands, check the temperature, and keep a distance (Direktorat Jenderal Pelayanan Kesehatan Kementerian Kesehatan, 2020). But for areas in the yellow, orange, and red zones are still prohibited from doing face-to-face learning at school and continue learning from home or online.

Based on the aforementioned review, empirical data was found in the form of observations and initial interviews which were then analyzed by researchers, that the implementation of the learning process of the full-day school program during the Covid-19 pandemic in New Normal, MIM PK had been carried out face-to-face according to the health protocol and policy recommendations from the government to prevent the spread of Covid-19. This can be seen from the implementation of the learning process that implements health protocols such as using masks, checking body temperature, arranging tables and chairs that are spaced out, there is a place to wash hands equipped with soap and hand sanitizers. The learning process also does not last for a full day, only a few hours to provide short material and also work to be done at home respectively. Also supported is data from interviews with school members who show that they can already understand the implementation of the Fullday School learning system to break the chain of distribution of Covid-19.

The limitation of this study is regarding the implementation of government policies related to the Fullday School program during the Covid-19 pandemic era of the new normal era following the health protocol. Changes to policy in the full-day curriculum program must be understood about what must be implemented, how it is implemented, and what should be a concern (Fauzi \& Sastra Khusuma, 2020). To improve and improve the quality of Indonesian education during the Covid-19 pandemic, efforts need to be made in the form of a procedure regarding the implementation of a full-day school program on how to implement it that meets the policy recommendations of the government in a school educational institution. Implementation of educational policies in this school certainly requires the cooperation of all school residents. This is supported by the opinion of Rusman that the key to success in implementing an educational program is the existence of a synergy of cooperation between the principal, teachers, and students properly (Rusman, 2015).

The policies adopted by the school in the learning process regarding the full-day school curriculum program during the Covid-19 pandemic New Normal era require collaboration from various parties of local society to make it a success. This research is supported by research conducted by Fauzi \& Khusuma which revealed that education during the Covid-19 pandemic can be carried out with various 
programs, namely 1) online learning, 2) the need for collaboration between all school members in the implementation of learning, 3) planning, implementation, and evaluation of appropriate learning and 4) collaboration with parents of students (Fauzi \& Sastra Khusuma, 2020). In this research, there is not yet a focus of research that focuses on how the implementation of the full-day school program during the Covid19 pandemic. Therefore, this study seeks to describe how the implementation of the full-day school program during the new normal Covid-19 pandemic in Indonesia following the health protocol policy government in carrying out learning face to face.

\section{Methods}

This research was conducted using a qualitative research approach with research methods, namely case studies. A qualitative research approach with this case study method according to Sugiyono is a research approach in which the focus of the research under study lies in the phenomena of events that occur naturally at present following the facts in the field (Sugiyono, 2018). This is reinforced by the opinion of Cresswell that this case study qualitative research is a research method that thoroughly investigates an event, program, and activity of a group of people (Cresswell, 2017). This qualitative research method usually uses the main problem formulation about how or why that is following the realities of real-world life not made up or manipulated because the researcher is not the person who influences the event, the researcher is only present as an observer/observer who has few opportunities to control the course of the phenomenon of the event being investigated.

The implementation of this research is based in a school called Madrasah Ibtidaiyah Muhammadiyah Wirogunan Special Program (MIM PK) which has an address in Kranggan Kulon Rt. 01 / Rw 02, Hamlet I, Wirogunan Village, Kartasura District, Sukoharjo Regency, Central Java Province, Indonesia with the postal code 57166. This madrasah implements a full day school curriculum system. However, the current condition of the Covid-19 pandemic made implementation limited and not optimal. The phenomenon that is happening and investigated in this research is focused on the phenomenon of how the procedure for implementing face to face learning changes in the curriculum of the Fullday School learning process during the Covid-19 pandemic as an effort to maintain and improve education at MIM PK. Data about the phenomenon of events collected in this study comes from qualitative data which is the result of collecting data using techniques that have been prepared to obtain accurate and targeted data.

The techniques used in collecting data are observation, in-depth interviews, questionnaires, and photo and video documentation. The instrument in collecting data in this qualitative research is the instrument that the researcher made himself because the researcher acts as a key instrument in the study. The instrument that the researcher made was equipped with guidance on observation guidelines, interview guidelines, questionnaire filling guidelines, and guidelines on what was documented through photos and videos. Researchers observed the learning process that was carried out by coming directly to MIM PK. Interviews conducted by researchers with school residents also took place safely and smoothly. Documentation in the form of photos and supporting videos to strengthen research evidence. The results of the data obtained are in the form of data about how the changes in the implementation of the full-day school learning process during the Covid-19 pandemic.

The instrument regarding data collection has a research subject as a target in retrieving data. The research subjects were 1 principal, 3 teachers, 4 students, and 4 students' parents who were included in the surrounding community. The selection of the subject of this study used a purposive sampling technique because to determine the subject of this data sample it had a close relationship with certain criteria determined by the researcher. This data will be obtained which further needs to be analyzed in depth. The data criteria used so that the data is said to be valid and valid are confirmability, transferability, dependability, and credibility. This study uses the degree of trust triangulation of data, namely the observation data collection in the form of notes in the field, the results of questionnaire filling data, documentation of data in the form of important letters, another important school has written documents, changes, and implementation of learning as well as interview results data in the form of head interview transcript schools, teachers, students and parents of students.

The data that has been collected and look for the degree of trust using triangulation of this data through checking of data to sources by comparing the results of transcripts with each other and a conclusion is made. The results of the data transcript are compared to guarantee the validity of the data by the researcher asking the informant to provide notes, additional information, and initial approval that the data collection has been done. The selection of data analysis aims to make the data more meaningful to be used to obtain a conclusion about the phenomenon of events that are happening from the data that has been obtained such as observational data, interview data, questionnaire results, and documentation data. The data that has been collected, reviewed, analyzed, and concluded can later be used as 
recommendations on how to change the curriculum of the full-day school program in the learning process of this Covid-19 pandemic.

Researchers need to prepare a research framework for studying, analyzing, and concluding how the researcher's thinking flow in a study. In this study, data analysis used to analyze data is using Miles and Huberman's interactive qualitative data analysis that is after the data is collected then the following procedures are performed: a) data reduction (simplification process on relevant data following focus of the research) is used to organize, manage, and direct the data so that conclusions and verification can be drawn, b) the presentation of data (data presented in the form of data reduction summarized and presented in an integrated manner) is used to gain an understanding of the phenomena that are happening to research, c) drawing conclusions (based on the phenomena and patterns formed) are used to get conclusions that are valid and no longer temporary about research (Sugiyono, 2018).

\section{Result and Discussion}

\section{Results}

\section{The Full day School Curriculum}

In the condition of the Covid-19 pandemic outbreak, the public would be aware of the various events and activities that would be carried out. Policy changes in the field of education, in particular, were implemented to facilitate the learning process while still seeing protection for school residents from Covid-19. One of the impacts is the change in the full-day school curriculum program. The policy regarding full-day school program is not required by all schools, its application is optional or optional, so each school may determine their respective school days according to conditions in the field. The curriculum used in the Full day School program is the integration of a balance between the general education curriculum from the Ministry of Education and Culture and the religious curriculum from the Ministry of Religion. Niam argue that a full-day school provides general education enriched with Islamic religious perspectives and education in learning activities to understand and practice knowledge (Niam, 2019).

Management in learning the full-day school curriculum during the Covid-19 pandemic certainly becomes very important, in addition to avoiding Covid-19 transmission, it can also improve innovation in the development of Indonesian education through variations in the implementation of learning conducted. This application is certainly to achieve the expected learning goals. The main learning goal is to remain following Law RI number 20 of 2003 concerning National Education System article 3 National education functions to develop capabilities and shape the dignified character and civilization of the nation to educate the life of the nation, aiming at developing the potential of students to become human beings of faith and devoted to God Almighty, noble, healthy, knowledgeable, capable, creative, independent and become citizens of a democratic and responsible.

The concept of full-day school learning curriculum in general according to government policy shown in Table 1.

Table 1. Full day School Curriculum Learning Concepts

\begin{tabular}{|c|c|c|}
\hline No & Curriculum & Explanation \\
\hline 1 & Study Time & $\begin{array}{l}\text { a. Class 1-3: At 07.00-14.30 WIB } \\
\text { b. Class 4-6: At 07.00-15.30 WIB }\end{array}$ \\
\hline 2 & Learning Day & $\begin{array}{l}\text { a. Monday-Friday is used for effective learning in a formal setting (three-four } \\
\text { hours a day) and an informal setting (seven to eight hours a day). } \\
\text { b. Saturday is used for compulsory extracurricular activities such as boy scouts } \\
\text { and student choices. }\end{array}$ \\
\hline 3 & $\begin{array}{l}\text { Curriculum } \\
\text { Forms }\end{array}$ & $\begin{array}{l}\text { Integration between the Ministry of National Education curriculum, the } \\
\text { Ministry of Religion curriculum, and the local content curriculum. }\end{array}$ \\
\hline 4 & Characteristics & $\begin{array}{l}\text { The number of activities that require active student participation activities, } \\
\text { because student activities in school are not limited to the class, but also there } \\
\text { are other activities outside of school. This activity is a daily activity of students } \\
\text { such as group learning, playing together, praying together, and so on. }\end{array}$ \\
\hline 5 & $\begin{array}{l}\text { Objectives and } \\
\text { targets }\end{array}$ & $\begin{array}{l}\text { Forming a generation of morality, achievement, and devotion to Allah SWT, } \\
\text { obedient to parents, active, creative, excel in achievement through a } \\
\text { combination of aspects of knowledge skills and attitudes that are Islamic } \\
\text { properly and proportionally. }\end{array}$ \\
\hline 6 & Extracurricular & $\begin{array}{l}\text { Students can channel their talents and interests towards soft skills and hard } \\
\text { skills through extracurricular programs. }\end{array}$ \\
\hline
\end{tabular}


The concept of full-day curriculum learning is certainly adjusted to the circumstances of each school, it does not require it to be the same as the guide. The Fullday School learning program provides education to students according to the needs of students and in line with what is desired by the community especially parents of students. Aziz \& Anwar argues that the Fullday School program combines formal school activities and non-formal activities to train students' character education especially Islamic religious education so that students can have Akhlaktul Karimah (Aziz \& Anwar, 2016). This is in line with the opinion of Arriandy, namely full-day school education is a school designed in the hope of being able to provide the best for the community through learning activities in schools (Ariandy, 2019). Niam also revealed that full-day school learning is packed with methods of developing and innovating the implementation of learning to develop the integration creativity of three domains namely cognitive, affective, and psychomotor (Niam, 2019).

\section{Preparations for Full Day School Learning}

In the condition of the Covid-19 pandemic, there were some changes in the policy of implementing full school learning. One of them is face-to-face learning which was initially suspended while later in the new school year 2020/2021 the government made a policy change in the face-to-face learning process that has several conditions that must be met to be carried out which was released in the Ministry of Education and Culture's press release, Nadiem Makarim announced the results of the decision on the June 15, 2020 webinar, namely: 1) a new school year for elementary / MI level and the same can begin in July 2020 which is in the green zone, while areas that enter the yellow, orange and red zones, are prohibited from doing face-to-face learning in their education units and must continue learning from home, 2) the local government must give permission, 3) if the school meets the checklist according to the health protocol, and 4) the parent or guardian of the student approves the student to do the learning face to face.

The full-day school learning program conducted by MIM PK in the new school year 2020/2021 has changed following the health protocol from the government. The changes implemented by the government regarding the implementation of the learning process in the school environment are certainly to avoid that students do not contract the Covid-19 virus. The impact of changes in government policy in learning is not only felt by students but also teachers, people, and parents. Learning that is usually face-toface where students can interact with their peers turn into completely restricted. Therefore Triyana, Djatmika, Wiyono argue that innovation and renewal in the development of full-day school systems are a solution so that face-to-face learning can be carried out (Triyana et al., 2018). In line with Dewi, the new changes in the learning system of the Covid-19 pandemic period require time to adapt. This time is used to welcome new learning innovations (Dewi, 2020).

To achieve these educational goals, of course, face-to-face learning must continue to be carried out even under these conditions, therefore we must adapt to policies regarding the learning process because face-to-face learning has tangible benefits and can be directly observed and felt. This is supported by the opinion of Husamah that face-to-face learning has various advantages for teachers and students, namely 1) formal school activities applied to face-to-face learning can shape student discipline, 2) facilitate the provision of reinforcement immediately, 3) facilitate the assessment process in learning, 4) can form the value of student character education effectively, and 5) becomes a vehicle for learning to interact and socialize (Husamah, 2015). The preparations made by MIM PK in meeting school requirements can conduct face-to-face learning that has been broadcast by the Ministry of Education and Culture before face-to-face learning can take place, shown in Table 2 .

Table 2. Terms of Implementation Face-to-face learning during the Covid-19 pandemic

\begin{tabular}{|c|c|c|}
\hline No & Terms & Results \\
\hline 1 & $\begin{array}{l}\text { The school is in a green } \\
\text { zone area }\end{array}$ & $\begin{array}{l}\text { Already fulfilled because at this time MIM PK is in the green zone area } \\
\text { to conduct face-to-face learning. }\end{array}$ \\
\hline 2 & $\begin{array}{l}\text { Local governments } \\
\text { must give permission }\end{array}$ & $\begin{array}{l}\text { Already fulfilled because MIM PK conducted discussions, permission } \\
\text { requests, and mediation with the Ministry of Religious Affairs } \\
\text { Sukoharjo, Wirogunan Kartasura Village, school committees, and } \\
\text { foundations related to learning conducted in person. }\end{array}$ \\
\hline 3 & $\begin{array}{l}\text { If the school meets the } \\
\text { health protocol } \\
\text { checklist }\end{array}$ & $\begin{array}{l}\text { It has been fulfilled because MIM PK has prepared recommendations } \\
\text { for government health protocol policies such as school residents } \\
\text { wearing masks, washing hands with soap and running water, } \\
\text { including to check body temperature, spraying disinfectants regularly, } \\
\text { and arranging distant class seats. }\end{array}$ \\
\hline
\end{tabular}




\begin{tabular}{lll}
\hline No & \multicolumn{1}{c}{ Terms } & \multicolumn{1}{c}{ Results } \\
\hline 4 & $\begin{array}{l}\text { Parents or guardians of } \\
\text { students approve } \\
\text { students doing face-to- } \\
\text { face learning }\end{array}$ & $\begin{array}{l}\text { It was fulfilled because MIM PK had held a discussion meeting about } \\
\text { face-to-face learning with students' parents, and in the end, the results } \\
\text { of the parents agreed to the agreement. }\end{array}$ \\
\hline
\end{tabular}

\section{The Changes in Full Day School Curriculum}

The Covid-19 pandemic period certainly did not dampen the enthusiasm for face-to-face learning because it was too long at home and in front of the gadget was not good for health. Halimah can be said that the full-day school learning system that is carried out face-to-face is a fun activity because in its activities there are habituations that can be directly practiced by students, this makes students easily learn them (Siti Halimah, 2019). There is a need for cooperation in good management, especially with effective learning time, structured teaching, and opportunities for learning so that changes in policy in the learning process can be achieved. To achieve these objectives, MIM PK in addition to meeting the requirements for holding face-to-face learning, the school also designed how the changes to the learning curriculum would be carried out following government recommendations and health protocols. The changes in the Full Day School Curriculum during the Covid-19 Pandemic shown in Table 3.

Table 3. Changes in the Full Day School Curriculum During the Covid-19 Pandemic

\begin{tabular}{|c|c|c|}
\hline Activity & $\begin{array}{c}\text { Old Curriculum } \\
\text { (Before Covid-19 Pandemic) }\end{array}$ & $\begin{array}{c}\text { New curriculum } \\
\text { (Current Covid-19 Pandemic) }\end{array}$ \\
\hline $\begin{array}{l}\text { New Student } \\
\text { Activity }\end{array}$ & $\begin{array}{l}\text { All students enter school, class } 5 \text { and } \\
\text { class } 6 \text { representatives present the } \\
\text { arts as entertainment, extracurricular } \\
\text { and Tahfizhul Qur'an. }\end{array}$ & $\begin{array}{l}\text { Only grade } 1 \text { is enrolled in school, for the } \\
\text { introduction of new students, new habits, } \\
\text { school residents, and a new environment in } \\
\text { the school. }\end{array}$ \\
\hline Learning Day & $\begin{array}{l}\text { a. Monday-Thursday is used for } \\
\text { effective learning. } \\
\text { b. Friday for self-development } \\
\text { especially regarding Islamic } \\
\text { Religious Education and soft skills } \\
\text { c. Saturday is used for the } \\
\text { implementation of compulsory } \\
\text { extracurricular and optional } \\
\text { extracurricular activities }\end{array}$ & $\begin{array}{l}\text { a. Monday and Thursday are used to give } \\
\text { the learning and assignments of } \\
\text { students in grades } 3 \text { and } 6 \text { briefly. } \\
\text { b. Tuesdays and Fridays are used to give } \\
\text { class } 2 \text { and } 5 \text { student learning and } \\
\text { assignments briefly. } \\
\text { c. Wednesday and Saturday are used to } \\
\text { give class } 1 \text { and } 4 \text { student learning and } \\
\text { assignments briefly. }\end{array}$ \\
\hline Learning Time & $\begin{array}{l}\text { a. Class 1-3 Student Study Hours } \\
\text { 07.30-14.30 WIB } \\
\text { b. Student Class Hours 4-6 At 07.30- } \\
\text { 15.30 WIB }\end{array}$ & $\begin{array}{l}\text { All class hours are the same, according to } \\
\text { each teacher starting at } 07.30 \text { WIB and not } \\
\text { more than } 10.00 \text { WIB. }\end{array}$ \\
\hline How to learn & $\begin{array}{l}\text { Full learning in school for one day by } \\
\text { way of face to face with the teacher }\end{array}$ & $\begin{array}{l}\text { In addition to the day of admission, } \\
\text { students are asked to learn from home and } \\
\text { online, which is guided by each classroom } \\
\text { teacher. }\end{array}$ \\
\hline Extracurricular & $\begin{array}{l}\text { Every Saturday, bring a trainer for } \\
\text { extracurricular activities. }\end{array}$ & $\begin{array}{l}\text { It remains on Saturday but is carried out } \\
\text { online and in each other's homes by only } \\
\text { providing material and practicing } \\
\text { independently }\end{array}$ \\
\hline
\end{tabular}

\section{Discussion}

The change in the full-day school curriculum program at MIM PK is the result of a coordination meeting and discussion with relevant institutions such as the foundation, Wirogunan Village, and the Ministry of Religion Sukoharjo which then permits implementation so that face-to-face learning can be carried out naturally by continuing to comply with preventive health protocols. Covid-19 as recommended by the government. Wicaksono argues that education will continue to experience dynamics that demand improvement and quality development following the times (Wicaksono, 2018). Adjustments need to be made with changes in education, especially during the Covid-19 pandemic to meet the needs of the community who ask for learning to be done face-to-face but must be safe. As can be seen in table 3, there are several differences between the old curriculum and the new curriculum. 


\section{Activity 1 for introducing new students (Awalussanah)}

This activity is intended to introduce new students to their environment, but during the Covid-19 pandemic, this activity was changed to a simple form that only class 1 entered by implementing the New Normal health protocol. This introduction period lasted only one day to invite grade 1 students to see the MIM PK environment which would be a place to gain knowledge. This activity is used to introduce the Foundation, the Principal, Teachers, and Employees as well as the rooms and facilities available. In the introduction of this new student, activities that become routine routines are also explained such as the Duha sunnah prayer, group prayer reading exercises, and group learning that will benefit in shaping the students' personality. This is supported by Ansari's opinion that in this full-day school learning, parents crave their children to be an intellectual generation who are intellectually intelligent and have an emotional social story and noble character (Ansari, 2015).

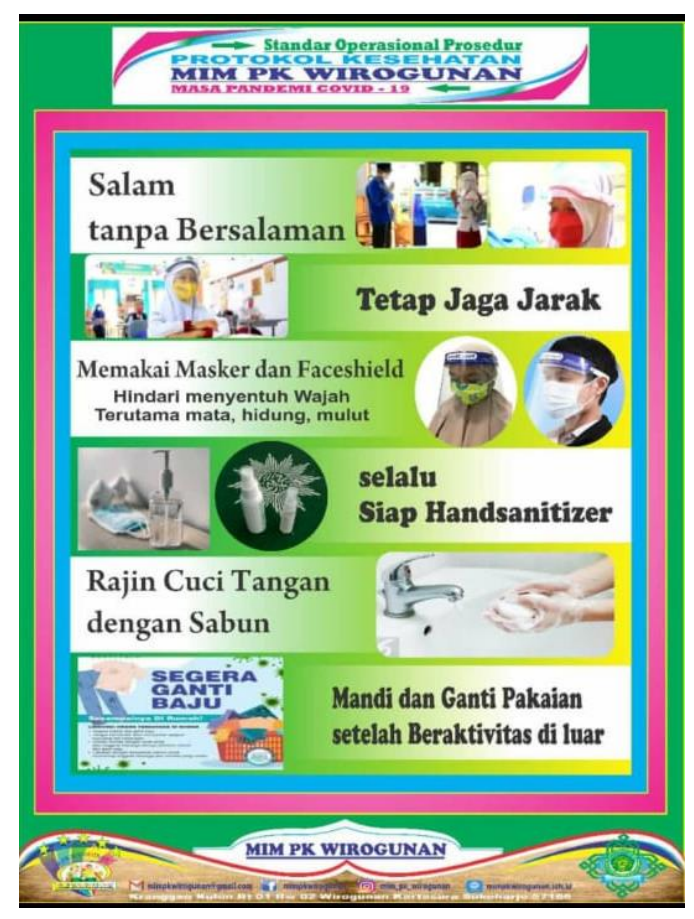

Figure 1. New Normal Health Protocol Procedures in MIM PK

Awalussanah activity also invited parents of grade 1 students to give notice of the learning process of the New Normal full-day school curriculum. The teacher gives a simulation to grade 1 student about the health protocol by practicing it and explaining it to be followed by grade 1 students who are assisted by their parents. This health protocol includes 1) greetings without shaking hands like saying good morning, good afternoon, morning sir/mom, 2) seating distance and keeping a distance from others, 3) wearing a mask and face shield, 4) before entering the mandatory class wash your hands with soap and running water, and 5) always ready to bring a hand sanitizer. This full school learning program has the meaning of Learning by doing which means learning through practice. This supported by the opinion of Sari, Wardani, \& Noviani that the best learning is to practice doing it directly so that you have experience (Ratna Sari et al., 2017).

\section{Activity 2 Learning Day}

The implementation of face-to-face learning programs in the curriculum of the full-day school program at MIM PK Karasura remains limited with students having to continue to obey health protocols during this pandemic. The change lies in the day of learning, in the new curriculum the day students enter school, not all of them enter. The division of turnover is a) Monday and Thursday are used to provide learning and assignments for students in grades 3 and 6 briefly, b) Tuesday and Friday are used to provide learning and assignments for students in grades 2 and 5 briefly, and c) Wednesday and Saturday are used to give class 1 and 4 student learning and assignments briefly. Class students who do not get a turn in when face-to-face learning continues to learn by learning from home via online, guided by their homeroom teacher with various online learning platforms. 
This policy change has proven effective by not making public crowds and face-to-face learning workable. The teacher certainly designs the implementation of the package which is packaged in a simple but already includes a lot of material, so that every opportunity to meet face to face with students can be conveyed to the maximum. The students also like that, even though learning does not come every day, he must do the assignments given by the teacher and continue to study independently at home accompanied by parents. If students encounter difficulties he can ask during face-to-face learning. This limited learning day must be used maximally by the teacher and students face-to-face with questions and answers and discussions about unclear learning material. Then, if the results are not yet finished, they will be continued and conveyed through online learning.

\section{Activity 3 Learning Time}

Changes to the full school curriculum program during the Covid-19 pandemic in terms of learning time were also limited. If it's in normal periode, it would be 07.30 WIB - 16.00 (Astuti, 2013). This is because students are not allowed to gather in the same place for a long period, so when it is time for students to enter school, the hour of entry starts at 07.30 WIB and should not be later than 10:00 WIB. If students leave early, they are even allowed with the notes that the material and assignment activities have been completed and have been consulted with the school principal. The assignment of tasks and material is not too much so as not to burden students and parents, only sufficiently important material is conveyed. Therefore, summarizing the important things for teachers and students in learning is very effective and efficient. Online learning is also done the same, starting from 07.30-10.00 WIB so that students can then rest and study independently working on learning tasks.

\section{Activity 4 How to learn}

In addition to student turnover, students are also asked to learn from home online, guided by their respective homeroom teacher. This online learning provides convenience and opportunities in a variety of conditions that can never be predicted so as not to make publicity at school. This is supported by the opinion of Khasanah, Pramudibyanti, \& Widoruyekti that in online learning trains cooperation, caring, mutual openness, and mutual assistance so that learning can run smoothly (Khasanah et al., 2020). The current condition urges innovation and adaptation related to the use of available technology to support the learning process (Ahmed et al., 2020). The practice requires educators and students to interact and transfer knowledge online. Online learning can take advantage of platforms such as applications, websites, social networks, and learning management systems (Gunawan et al., 2020).

These various platforms can be utilized to support knowledge transfer supported by various discussion techniques and others. Teachers can use WA groups, as well as Google classroom. This is because online learning allows access to information and knowledge at home and anywhere that is tailored to the convenience of students (Herliandry, Nurhasanah, Suban, \& Heru, 2020). Online learning requires the role of educators to evaluate its effectiveness and adapt it to learning needs (Efendi \& Neng, 2018). This is important to do to keep up with aspects of learning such as the process of knowledge, morals, skills, intelligence, and aesthetics (Zhou et al., 2020). Given that changes to online learning indirectly affect the absorption of students (Dewi, 2020). Therefore, it is important to note that the communication of parents and educators to realize the independence of student learning during the Covid-19 pandemic period of the new normal era.

\section{Activity 5 Extracurricular}

The last change is in extracurricular activities. An extracurricular activity or extra academic activity is an activity, performed by students, that falls outside the realm of the normal curriculum of school, college or university education. Such activities are generally voluntary, social, philanthropic, and often involve others of the same age (Kadi, 2015). This extracurricular activity is still held on Saturday after the student turn in or the learning is finished, which is after 10:00 WIB This activity is still carried out because with these extracurricular activity students can develop their potential in terms of soft skills and hard skills. The extracurricular must scout and choice. This activity is only for classes 3-6, whereas for classes 1-2 the focus is on Calistung (Read and Count) skills. In extracurricular choices, students are free to choose extracurricular activities such as archery, computer clubs, singing choirs, basketball, soccer, futsal, karate, Pencak silat, taekwondo, judo, Qiroah, and Dai Cilik. Each of these extracurricular activities will usually bring in a trainer but during the Covid-19 period, it is enough to provide material online and ask students to learn and practice it directly and independently. 


\section{Conclusion}

Based on the results of the study, it can be concluded that MIM PK has met the requirements for face-to-face learning in schools with health protocols as recommended by the government. Face-to-face learning is carried out safely, such as before entering the school area, students are checked for body temperature and asked to wash their hands with soap and running water. Don't forget to wear a mask, face shield, and keep your distance from each other. The schedule for entering school in providing learning and assignments is limited and varies according to class, where Monday and Thursday are used for grades 3 and 6, Tuesday and Friday are used for grades 2 and 5, while Wednesday and Saturday are used for grades 1 and 4. All class hours are the same, according to each teacher starting at 07.30 WIB and not more than 10.00 WIB. This is done to avoid crowds of students because they still like to play with their friends. The efforts made by the school have been very good. The implementation of several changes to health regulations and protocols encourages the emergence of social distancing behavior and minimizes the possibility of a crowd in the school community. Some recommendations from the researchers, by holding face-to-face learning, schools must be extra careful in supervising their students in implementing health protocols, not to be careless. At times like this, of course, everyone experiences their difficulties, if students cannot apply health protocols, schools must provide several facilities such as giving masks, face shields, hand sanitizers. it can also be in the form of reducing school fees, providing guidance to truly underprivileged students, and not forcing students to enter school but are still supervised and given guidance to achieve learning goals. The key is to pay attention to and maintain health hygiene starting from yourself during the Covid-19 pandemic.

\section{References}

Ahmed, S., Shehata, M., \& Hassanien, M. (2020). Emerging Faculty Needs for Enhancing Student $\begin{array}{lllll}\text { Engagement on a Virtual Platform. MedEdPublish, } & \text { 9(1), }\end{array}$ https://doi.org/10.15694/mep.2020.000075.1.

Ansari, M. (2015). Strategi Sistem Full Day School dalam Membentuk Empati Siswa. Muallimuna : Jurnal Madrasah Ibtidaiyah, 1(1), 70-78. https://doi.org/10.31602/muallimuna.v1i1.276.

Ariandy, M. (2019). Kebijakan Kurikulum dan Dinamika Penguatan Pendidikan Karakter di Indonesia. Sukma: Jurnal Pendidikan, 3(2), 137-168. https://doi.org/10.32533/03201.2019.

Astuti, M. (2013). Implementasi Program Fullday School Sebagai Usaha Mendorong Perkembangan Sosial Peserta Didik TK Unggulan Al-Ya'lu Kota Malang. Jurnal Kebijakan Dan Pengembangan Pendidikan, 1(2), 133-140. https://doi.org/10.22219/jkpp.v1i2.1561.

Aziz, Z., \& Anwar, K. (2016). Kurikulum terpadu: model pembinaan karakter pada sekolah islam fullday. IJER (Indonesian Journal of Educational Research), 1(2), 81-90. https://doi.org/10.30631/ijer.v1i2.19.

Cresswell, J. W. (2017). Research Design Pendekatan Kualitatif, Kuantitatif, dan Mixed Edisi ketiga. Pustaka Pelajar.

Dewi, W. A. F. (2020). Dampak CoVID-19 terhadap Implementasi Pembelajaran Daring di Sekolah Dasar. Edukatif: Jurnal Ilmu Pendidikan ,2(1), 55-61. https://doi.org/10.31004/edukatif.v2i1.89.

Direktorat Jenderal Pelayanan Kesehatan Kementerian Kesehatan. (2020). Petunjuk Teknis Pelayanan Pada Masa Pandemi Covid-19. Kementerian Kesehatan RI.

Efendi, Neng, M. (2018). Revolusi Pembelajaran Berbasis Digital (Penggunaan Animasi Digital Pada Start Up Sebagai Metode Pembelajaran Siswa Belajar Aktif). Habitus: Jurnal Pendidikan, Sosiologi, Dan Antropologi, 2(2), 173-182. https://doi.org/10.20961/habitus.v2i2.28788.

Fauzi, I., \& Sastra Khusuma, I. H. (2020). Teachers' Elementary School in Online Learning of COVID-19 Pandemic Conditions. Jurnal Iqra': Kajian Ilmu Pendidikan, 5(1), 58-70. https://doi.org/10.25217/ji.v5i1.914.

Gunawan, Suranti, N. M. Y., \& Fathoroni. (2020). Variations of models and learning platforms for prospective teachers during the COVID-19 pandemic period. Indonesian Journal of Teacher Education, 1(2), 61-70. https://journal.publication-center.com/index.php/ijte/article/view/95.

Herliandry, L. D., Nurhasanah, N., Suban, M. E., \& Kuswanto, H. (2020). Pembelajaran Pada Masa Pandemi 
Covid-19. JTP - Jurnal Teknologi Pendidikan, 22(1), 65-70. https://doi.org/10.21009/jtp.v22i1.15286.

Husamah, H. (2015). Blended Project Based Learning: Metacognitive Awareness of Biology Education New Students. Journal of Education and Learning (EduLearn), 9(4), 274-281. https://doi.org/10.11591/edulearn.v9i4.2121.

Iftayani, I. (2016). Self Concept, Self Esteem and School System: the Study of Comparation Between Fullday School and Halfday School in Purworejo. Muhammadiyah University Metro.

Izzah, I. (2018). Peran Pendidikan Agama Islam Dalam Membentuk Masyarakat Madani. Pedagogik: Jurnal Pendidikan, 5(1), 50-68. https://doi.org/10.33650/pjp.v5i1.219.

Kadi, T. (2015). Model Kurikulum Fullday School dengan Sistem Terpadu di Sekolah Dasar (SD) Islam Terpadu Cordova Samarinda. SYAMIL: Jurnal Pendidikan Agama Islam (Journal of Islamic Education), 3(1). https://doi.org/10.21093/sy.v3i1.242.

Khasanah, D. R. A. U., Pramudibyanto, H., \& Widuroyekti, B. (2020). Pendidikan Dalam Masa Pandemi $\begin{array}{llll}\text { Covid-19. Jurnal } & \text { Sinestesia, } & \text { 10(1), }\end{array}$ https://sinestesia.pustaka.my.id/journal/article/view/44.

Kristi Pramudika Sari, A., Fajrul Falah, I., Muhammadiyah Kuningan Jl Murtasiah Soepomo, S., \& Kuningan, B. (2018). Perbedaan Stress Level Siswa Sekolah Dasar Antara Full-Day Dan Half-Day School Di Kabupaten Kuningan. Jurnal Ilmiah Educater, 4(2), 142-148. http://jurnal.upmk.ac.id/index.php/educater/article/view/413.

Librianty, N. (2018). Pengelolaan Pendidikan Fullday School di Sdn 002 Bangkinang Kota Kabupaten Kampar. Jurnal Basicedu, 2(1), 69-76. https://doi.org/10.31004/basicedu.v2i1.27.

N Niam, Z. W. (2019). Membina Karakter Anak Melalui Program Full Day School Berbasis Nilai-Nilai Kepesantrenan (Studi Kasus di Madrasah Ibtidaiyah Nurul Ummah Kotagede Yogyakarta). Belajea; Jurnal Pendidikan Islam, 4(1), 19-34. https://doi.org/10.29240/belajea.v4i1.696.

Sari, P. R., Wardani, D. K., \& Noviani, L. (2017). Implementasi full day school (sekolah sehari penuh) sebagai best practice (latihan terbaik) dalam pendidikan karakter di SMA Negeri 1 sragen. BISE: Jurnal Pendidikan Bisnis dan Ekonomi, 3(2). https://doi.org/10.20961/bise.v3i2.16452.

Rusman. (2015). Pembelajaran Tematik Terpadu : Teori, Praktik dan Penilaian. Rajawali Press.

Setiyarini, Joyoatmojo, S. (2014). Penerapan Sistem Pembelajaran "Fun \& Full Day School" untuk Meningkatkan Religiusitas Peserta Didik di SDIT Al Islam Kudus. Teknologi Pendidikan Dan Pembelajaran, 2(2), 231-244. http://jurnal.fkip.uns.ac.id.

Halimah, S. (2019). Membangun Kecerdasan Spiritual Siswa Melalui Sistem Full Day School Di SDIT Bina Insan Cendekia Kota Pasuruan. Jurnal Al Makrifat, 4(2). https://core.ac.uk/download/pdf/234800682.pdf.

Sugiyono. (2018). Metode Peneiltian Kuantitatif, Kualitatif dan R\&D. Alfabeta Bandung.

Triyana, J. P., Djatmika, E. T., \& Wiyono, B. B. (2018). Sistem Full Day School dalam Menguatkan Karakter Peserta Didik Sekolah Dasar. Jurnal Pendidikan: Teori, Penelitian Dan Pengembangan, 3(12), 1550-1560. http://journal.um.ac.id/index.php/jptpp/.

Wicaksono, A. G. (2018). Fenomena Full Day School Dalam Sistem Pendidikan Indonesia. Jurnal Komunikasi Pendidikan, 1(1), 10. https://doi.org/10.32585/jkp.v1i1.12.

Zhou, L., Wu, S., Zhou, M., \& Li, F. (2020). 'The Largest Online Education in the World Today: Taking China's Practical Exploration During The COVID-19 Epidemic Prevention and Control As an Example (March 15, 2020). https://doi.org/10.2139/ssrn.3555520. 